\title{
9/8 ROMAN DANSI Kültür, Kimlik, Dönüşüm ve Yeniden İnşa Gonca GİRGIN
}

İstanbul: Kolektif Kitap, 2015, Türkçe, 312 Sf.

ISBN: 978-605-502-941-8

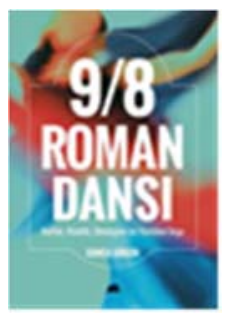

\section{Cihan GIREYHAN*}

Gonca Girgin, İstanbul Teknik Üniversitesi (İTÜ) Türk Müziği Devlet Konservatuvarı Temel Bilimler Bölümü mezunu olup, İTÜ Türk Musikisi Devlet Konservatuarı Müzikoloji Bölümü’nde öğretim üyesidir. Yüksek lisans ve doktora eğitimleri süresince yöneldiği kültürel çalışmalar alanında kimlik, kültür politikaları, etnisite gibi konular üzerine araştırmalar yapan Girgin, 9/8 Roman Dansı kitabının önsözünde kitabın yazılma amacını aşağıdaki gibi vurgulamıştır:

Kimliksel temsillerin belki de en dikkat çeken tarafı olan etnik kimlik meselesinde yeni bir tartışma ortamı yaratmak temel amaçlarımdan biri. Çünkü kimliksel inşa süreçlerini Çingeneler üzerinden incelediğimde, mesele etnisite, vatandaşlık, millet olma vb. kavramların ötesinde kültürel alana dair. Buradaki niyetim "etnisite" başlığını yok saymak değil, aksine kültürel kimliğin "etnisite" kelimesiyle içine girilen, üretilen, yapılandırılan, çerçevelenen ve şekillenen yapısının dinamiklerini anlayabilmek (Girgin 2015: 11-12).

Yazarın da belirttiği gibi kitapta etnisite, kimlik ve milliyetçilik kavramları, toplumsal ve siyasal değişimler sonucunda yeniden ele alınmaktadır. $\mathrm{Bu}$ yeniden ele alış, kavramlara yüklenen anlamların değişimine neden olmaktadır. Çingene-Roman kimliği son dönemde iyiden iyiye küresel ekonomilerin, hızlı kültürel ve toplumsal dönüşümlerin popüler kaynaklarından

\footnotetext{
Kitap Tanıtımı Geliş Tarihi: 29.05.2018 Kabul Tarihi: 18.06.2018

* Ege Üniversitesi Sosyal Bilimler Enstitüsü Türk Halk Oyunları Anabilim Dalı, Yüksek Lisans Öğrencisi, cihangireyhan@gmail.com

ORCID ID: https://orcid.org/0000-0003-3648-971X
} 
biri olduğundan karmaşık bir yapı ortaya çıktığından bahsetmektedir. 9/8 Roman Dansının kültürel bir ürünken ticari bir ürün haline evrilmesini, bedensel değişimler ve kimliksel dönüşümler üzerinden somutlaştırılan bu çalışma, analitik açıdan önem taşımaktadır. Ayrıca kitapta Roman Dansının kültürel, sanatsal bir faaliyet oluşunun yanı sıra Çingene-Roman, Roman Dansı ile ilgili tartışmalara açıklık getiren bilgiler verilmiştir. Dolayısıyla bu kitabın diğer katma değeri de, üniversitelerde eğitimi verilen halk oyunları sanat dalı alanına bu terminolojiyi kazandırmasıdır. Öğrenme ve öğretme becerilerine katkı sağlayacak olan bu terminoloji, emik yaklaşımı benimsemenin gerekliliğine inanıldığı için Roman Havası, Roman Dansı, Türk halk oyunları, halk dansları vb. terimleri yaygın olarak bilindiği şekliyle kullanılmıştır.

Kitap beş bölümden oluşmaktadır. Birinci bölümde; Etnik kimlik tanımlarına, kimlik çalışmalarının dansla ilişkisine, kimlik odaklı çalışmalara, Dini, milli, etnik ya da grup kimliklendirmelerindeki manipülasyon süreçlerinin karmaşık yapısına, Türkiye'de Çingene ve Roman kimliğinin dönüşüm sürecinde dans ortamları ve gösterimlerine yer verilmiştir. Sohbet ortamlarında elde edilen her türlü kültürel ve toplumsal bilgi kaydedilerek dans ortamlarına dair analizlerde anlamları kültürel yapıyla ilişki üzerinden açıklanmıştır. Yazar, alanda yaptığı araştırmalar sırasında yerel bilgiye ulaşmasının zorluklarını anlatmıştır.

Edindiği yüzlerce kaydı izledikten sonra alan araştırmalarını yoğunlaştırmayı ve özellikle kadınlarla dans edebilme olanaklarını arttırmayı planlamıştır. Alan çalışmaları ve elde edilen etnografik verilerin değerlendirme sürecinde diğer bedenler üzerinden kendi bedenini anlamlandırmaya çalışmış ve Çingene-Roman kadınlarının dans repertuarlarındaki karmaşıklığına değinmiştir.

İkinci bölümde ise, genel anlatımlar 1şığında yapılan experiri-kültürel kimlik adlandırmasına Çingene-Roman toplulukları üzerinde yapılan incelemelerle açılık getirilmiştir ve Çingene-Romanların varlıklarının tarihsel süreci anlatılmıştır. Ayrıca Çingene-Romanların yaşadıkları müzikal kültürün zaman geçtikçe nasıl popülerleştiğinden bahsetmiştir. Son olarak ÇingeneRoman danslarında görülen "doğaçlama" yani bölgesel farklılıklardan kültürel olarak şekillenen koreografilere değinilmiştir.

Üçüncü bölümde yazar, Çingene-Roman olmak kavramı üzerinde durmuştur. Ayrıca Çingene-Roman kültürünün sadece Türkiye'de değil diğer ülkelerdeki (Avrupa, Bulgaristan, Makedonya, Arnavutluk) popülerleşme sürecini anlatmıştır. 9/8'lik Roman oyun havasının günümüzde eğlencenin ilk sıralarına çıkma aşamalarını değerlendirmiş, dans ve müzik alanındaki 
başarısının sebebinin "samimi, olduğu gibi, egzotik, tutkulu" kavramları etrafında döndüğü sonucuna varmıştır.

Dördüncü bölümde ise; tarihsel verilerin günümüzle ilişkisini anlama, açıklama ve analiz etme süreci iki farkl1, ama iç içe görünüm üzerinden açıklanmıştır. Günümüz popüler Roman dansının çeşitli kültürlere sıçramasının sebebinin kültürün dinamik olması, öte yandan tarihselleşmesi, değişmesi, korunması, unutulması, kuşaklar aracılığıyla yeniden yorumlanması gibi dinamikler sayesinde bugün Roman dansı vb. oyunların izlerinin görüldüğünden bahsedilmektedir.

Ayrıca Osmanlı Çingene İcraları, Dansözlük, Sulukule Eğlence Evleri, Trakya Karşılamalarında Romanlı Doğaçlamalar, Edirne Roman Müzikleri Topluluğu'nun çağrıştırdıkları, Romanlı Trakya karşılamalarından tarihsel süreçlerindeki değişim ve gelişiminden yine bu bölümde bahsedilmiştir. Osmanlı çengi ve köçek icralarının Cumhuriyetle birlikte nasıl ötekileştirildiğine dördüncü bölümün sonunda yer verilmiştir.

Son bölümde ise; yerel pratiklerdeki hareket repertuarı tasvirleri, alan araştırmaları sürecinde yoğunlukla gözlemlenen, her statüden ve her yaştan mahallenin genellikle uyguladığı temel hareket ve dizileri örneklenmektedir. Ayrıca Trakya Karşılaması ve 9/8'lik Roman dansının temel özellikleri ve yapısal analizine değinilmiştir.

Kitapta Roman Dans1; Antropolog Kaeppler'in hareket analiz sistemi kullanılarak detaylı bir şekilde anlatılmıştır. Geleneksel repertuarın günümüzde genişleyen hareket sözlüğü en çok alt beden farklılıklarının olduğunu gözlemlemiş ve Çingene olmayanların dansları, Televizyon dizileri, Roman müzik ve dans yarışmaları, şov programları, toplumsal Romanlaşma ve son olarak gelinen Tekno-Roman Dansı hakkında bilgiler vermiştir.

Yazar bu çalışmasında, Çingene-Roman topluluklarının bir etnik grup olarak benimsendiğini, tartışma alanının etnisite ve etnik grup yakıştırmaları ile kültürel ve experiri kültürel kimlik niteliğinin arasında olduğunu belirtmektedir. Amacının ise; halkların özgürlük ve eşitlik koşullarını da vurgulamak için, etnik grup olarak belirlenmiş kurgusal "kalabalığın" kültürel bir varlık olarak tanınması olduğunu vurgulamıştır. Bütün kültürel grupların nitelik açısından farklı olduğunu, ancak nicel ve temel haklar açısından aynılığı ve eşitliği de barındırdığını düşünmektedir.

Roman Dansının kültürel derinliği ve geldiği nokta, popülarite ve bedensel temsiller açısından detaylı analizi yapılan bu kitap konuyla ilgili çalışma yapmak isteyen araştırmacılara son derece yararlı olacaktır. 